\title{
INHIBITORY EFFECTS OF SOME PESTICIDES AND METALS ON CARBONIC ANHYDRASE PURIFIED FROM SHABUT FISH (BARBUS GRYPUS) GILL TISSUE
}

\author{
YERLIKAYA, E. \\ School of Health, Siirt University, 56100 Siirt, Turkey \\ (e-mail: emrahyerlikaya@siirt.edu.tr; phone: +90-484-223-1224/4054; fax: +90-484-223-5156) \\ (Received $7^{\text {th }}$ Jul 2019; accepted $2^{\text {nd }}$ Sep 2019)
}

\begin{abstract}
Carbonic anhydrase enzyme catalyzes the reversible inter-conversion of $\mathrm{CO}_{2}$ and $\mathrm{HCO}_{3}$. The enzyme is crucial for the osmotic balance and acid-base regulation in the fish. It is well-known that gills of fish play the most important role in acid-base relevant ion transfer, the transfer of $\mathrm{H}^{+}$and/or $\mathrm{HCO}_{3}$, for the maintenance of systemic $\mathrm{pH}$. Many researches have shown that fish are the species that is the most susceptible to environmental toxins. In addition, these toxins firstly encounter the gill tissue in fish. In this study, the carbonic anhydrase enzyme was purified 198.6-folds with 58.8\% yield from Shabut Fish (Barbus grypus) gill tissue by Sepharose-4B-L-tyrosine-sulfanilamide affinity column. The specific activity was determined as $2.92 \mathrm{EU} / \mathrm{mg}$ protein. The molecular weight determined by sodium dodecyl sulfate-polyacrylamide gel electrophoresis was found to be about $29.9 \mathrm{kDa}$. Inhibitory effects of some pesticides (Spinosad and Dimethoate) and metal ions $\left(\mathrm{Al}^{3+}, \mathrm{Cu}^{2+}, \mathrm{Ba}^{2+}, \mathrm{Fe}^{2+}, \mathrm{Mn}^{2+}, \mathrm{Se}^{2+}\right.$ ) were examined on the purified carbonic anhydrase enzyme. Inhibition graphics were drawn in order to find the $\mathrm{IC}_{50}$ values of metals and pesticides showing inhibition. The kinetic parameters of this enzyme were determined for its esterase activity, with 4-nitrophenyl acetate as substrate.
\end{abstract}

Keywords: pollution, inhibition, enzyme, chromatography, catalysis

\section{Introduction}

According to the records of the Food and Agriculture Organization, Shabut, also known as Barbus grypus, is one of the most significant fish species listed in the fresh waters of Iraq and in the rivers along South and Southwest Iran, the Karoon river, and also in The Euphrates River and Tigris Rivers in Turkey (Olgunoglu et al., 2011). Shabut is one of the leading fish species of Siirt/Botan Stream which contributes to the city's economy.

In nature it is known that carbonic anhydrases (CAs, EC 4.2.1.1) are some of the most efficient enzymes probably due to the fact that uncatalyzed $\mathrm{CO}_{2}$ hydration is a very slow process at neutral $\mathrm{pH}$, and the physiologic demands for its conversion to ionic, soluble species (i.e., bicarbonate and protons) are very high. Actually, $\mathrm{CO}_{2}$ is generated in most metabolic oxidative processes, and being a gas, it must be converted to soluble products quickly and efficiently. Otherwise, it could accumulate and damage cells and other organelles in the gaseous state without such an efficient hydration catalyst as the CAs (Supuran, 2018). At least 16 different $\mathrm{CA}$ isozymes have important roles in diverse processes, such as physiological $\mathrm{pH}$ control and gas balance, calcification, and photosynthesis, have been described in higher vertebrates up to this point. The role of $\mathrm{CA}$ in fish gills is considered to be related to gas exchange, acid-base balance, osmoregulation, ion regulation, and clearance of the waste products from nitrogenous metabolism. The shape of distribution of CA activity among gills pairs shows variety depending on habitat and osmoregulatory behavior of the animal. Gill epithelium is the first tissue of the organism exposed to the aquatic environment, and because of this, it is the primary frontier for the harmful effects of environmental pollutant in the case of fish (Lopez Mananes et al., 2000; Randall and Daxbaeck, 1984; Dincer et al., 2016; Hisar et al., 2004). 
The gill tissue is the primary tissue contacting with the contaminants in the water. Because of its small diffusion distance and large surface area between the blood and water, the gills are initially affected by contaminants such as pesticides and metals (Demir et al., 2016). In general, the gill cells react rapidly to several chemicals to handle tissue damage or physiological impairment. Chemicals may have a negative impact on the overall gill function, improving fish sensitivity to toxic compounds and potentially causing fish mortality (Cerqueira and Fernandes, 2002). Lately, the contamination of aquatic environment by pollutants has become a big problem. They are a threat to public water supplies and can damage aquatic life (Koca et al., 2005). Pesticides are substances that are used to kill or control the organisms considered to be destructive. The most broadly used ones are insecticides, herbicides, fungicides and rodenticides. They are the most common contaminants of the environment and cause water, soil and air pollution. They can also pile up in the living organisms like humans, animals, and so on (Anwar, 1997). They are attracted attention owing to the fact that they stay in the environment for a long time, can accumulate in food, and have a constant presence in food and drinking water (Tiemann, 2008). Generally, pesticides can interfere into rain water, irrigation water or river, plants and may be harmful for specific enzymes. It is known that many compounds, metal ions and pesticides can be hazardous for the living organisms in water. Scientific studies on pesticides make clear that these compounds show their destructive effects by inhibiting the enzymes even at low concentrations (Ceyhun et al., 2010).

Heavy metals have a toxic impact that is proportional to their concentration in fish. Heavy metals bring about toxicity in aquatic environments and this heavy metal damage is a crucial factor in many toxicological and pathological processes (Ekinci and Beydemir, 2010; Soyut and Beydemir, 2008). At the same time, heavy metals may lead to oxidative damage by decreasing the cellular antioxidant capacity and by directly rising the cellular concentration of reactive oxygen species (Topal et al., 2014; Ekinci et al., 2008). It has been reported that heavy metals and pesticides principally enter into the human/animal body through ingestion, such as food materials, inhalation and dermal contact, such as emissions of waste material in the form of smoke, dust particle, fume of chemicals from several industrial activities, such as mining, and manufacturing of batteries (Singh et al., 2017).

The aim of the study is to purificate and examine the inhibition effects of the some pesticides and metals on the activity of CA enzyme from Shabut Fish (Barbus grypus) gill tissue in the Tigris basin. Since it is frequently consumed by the people of the region and has high economic value, Shabut Fish was chosen as the source in the study. In addition, since CA enzyme has never been purified from this fish species before, this fish species was preferred in the study. The other aim of the study is the determination of some biochemical parameters of purified enzyme. For this purpose, the enzyme was isolated from gill of this fish. It was determined the inhibitory effects of these chemicals using 4nitrophenyl acetate (4-NPA) as a substrate.

\section{Methods and materials}

\section{Chemicals and devices}

All chemicals used in this study were the highest grade purity available and were obtained from Sigma and E. Merck (Darmstadt, Germany). Sepharose 4B activated by $\mathrm{CNBr}$, protein assay reagents, and chemicals for electrophoresis were obtained from Sigma-Aldrich Chemie (Taufkirchen, Germany). A UV-Visible spectrophotometer 
(VWR UV-6300PC Double Beam Spectrophotometer) was used for the determination of enzyme activity. The peristaltic pump used for enzyme purification was (Masterflex L/S Digital Pump System 77921-60), the centrifuge machine was purchased from Thermo Scientific/Megafuge 16R and the electrophoresis system was a Bio-Rad MiniPROTEAN®System.

\section{Preparation of homogenate}

Shabut Fish (Barbus grypus) gill tissues were obtained commercially from fishermen in Siirt/Botan Stream, Turkey. Gill tissues were brought to Siirt University Science and Technology Application and Research Center Laboratory in accordance with the cold chain rule. They (about $50 \mathrm{~g}$ ) were cut off carefully with aid of scalpel for avoiding damage and were washed three times with $0.9 \% \mathrm{NaCl}$ to eliminate blood and other contaminants. After the tissues were lysed by liquid nitrogen, were taken in $50 \mathrm{mM}$ Tris-SO $\mathrm{SO}_{4}$ buffer ( $\mathrm{pH}$ 7.4). The homogenate was centrifuged for $60 \mathrm{~min}$ $\left(15.000 \mathrm{rpm}\right.$ at $\left.+4{ }^{\circ} \mathrm{C}\right)$. The $\mathrm{pH}$ of the resulting supernatant was adjusted to 8.7 with solid Tris and loaded onto the affinity column.

\section{Purification of CA from Shabut Fish (Barbus grypus) gill by affinity chromatography}

The solution was applied to a Sepharose 4B-L-tyrosine sulfanilamide affinity column equilibrated with $25 \mathrm{mM}$ Tris- $\mathrm{HCl} / 0.1 \mathrm{M} \mathrm{Na}_{2} \mathrm{SO}_{4}(\mathrm{pH} \mathrm{8.7)}$. The affinity gel was washed with $25 \mathrm{mMTris}-\mathrm{HCl} / 22 \mathrm{mM} \mathrm{Na}_{2} \mathrm{SO}_{4}(\mathrm{pH}$ 8.7). CA was eluted with $0.1 \mathrm{M} \mathrm{NaCH} 3 \mathrm{COO} / 0.5 \mathrm{M} \mathrm{NaClO}_{4}(\mathrm{pH} 5.6)$. The $280 \mathrm{~nm}$ absorbance of the protein in the column effluents was determined spectrophotometrically. All of the purification steps were performed at $4{ }^{\circ} \mathrm{C}$.

\section{Esterase activity assay}

The CA activity was assayed by the esterase method by following the change in absorbance at $348 \mathrm{~nm}$ of 4-NPA hydrolyzed to 4-nitrophenolate ion in the presence of the enzyme, over a period of $3 \mathrm{~min}$ at $25{ }^{\circ} \mathrm{C}$, using a UV-Vis spectrophotometer according to the Verpoorte procedure (Verpoorte et al., 1967). The enzymatic reaction, in a total volume of $1.0 \mathrm{~mL}$, contained $0.59 \mathrm{~mL}$ Tris-SO4 buffer solution (50 mM, pH 7.4), $0.36 \mathrm{~mL} 4-N P A(3.0 \mathrm{mM})$, and $0.05 \mathrm{~mL}$ enzyme. The control cuvette did not contain enzyme solution. One enzyme unit of CA esterase activity is defined as hydrolysis of $1 \mu \mathrm{mol} 4-\mathrm{NPA}$ to p-nitrophenol and acetate in $1 \mathrm{~min}$. Briefly, 4-NPA is hydrolyzed into p-nitrophenol and acetate by CA, and p-nitrophenol absorbance is determined spectrophotometrically at $348 \mathrm{~nm}$ for CA esterase activity. The absorbance of the non-catalyzed 4-NPA in this buffer was always subtracted from the enzymatic measurements reported in this article (Senturk et al., 2011). $\mathrm{K}_{M}$ and $\mathrm{V}_{\max }$ values were calculated for NPA by Lineweaver-Burk graph (Lineweaver-Burk, 1934).

\section{Protein determination}

During each purification steps, protein determination was performed spectrophotometrically at $595 \mathrm{~nm}$ according to the Bradford method, using bovine serum albumin as the standard (Bradford, 1976). 


\section{SDS polyacrylamide gel electrophoresis}

Sodium dodecyl sulfate-polyacrylamide gel electrophoresis (SDS-PAGE) was carried out according to the method of Laemmli for the determination of purity and molecular weight of the Shabut Fish (Barbus grypus) gill CA using a 5\% (w/v) stacking gel and 12\% (w/v) separating gel (Laemmli, 1970). The molecular weight of the enzyme was determined using different protein markers from $8.5 \mathrm{kDa}$ to $70 \mathrm{kDa}$. $R_{f}$ values were also calculated for the enzyme and standard proteins, and $R_{f}-\log M W$ graph was obtained (Fig. 1).

\section{Optimum pH determination}

In order to determine the optimum $\mathrm{pH}, \mathrm{K}$-phosphate and Tris- $\mathrm{SO}_{4}$ buffers were used in the $\mathrm{pH}$ range of 5.0-7.5 and 7.0-9.0, respectively.

\section{Optimum temperature determination}

For determination of the optimum temperature, enzyme activity was assayed at different temperatures in the range from 5 to $70{ }^{\circ} \mathrm{C}$. The desired temperature was provided by using a Grant bath.

\section{Optimum ionic strength determination}

For determination of optimum ionic strength, enzyme activity was determined using different concentrations of Tris- $\mathrm{SO}_{4}$ buffer, $\mathrm{pH}$ : 7.5 , in the range from $10 \mathrm{mM}$ to $1000 \mathrm{mM}$.

\section{Inhibition effect of some pesticides and metals on CA enzyme activity}

The inhibitory effects of some pesticides (Spinosad and Dimethoate) and metal ions $\left(\mathrm{Al}^{3+}, \mathrm{Cu}^{2+}, \mathrm{Ba}^{2+}, \mathrm{Fe}^{2+}, \mathrm{Mn}^{2+}, \mathrm{Se}^{2+}\right)$ were determined on Shabut Fish (Barbus grypus) gill CA enzyme activity. The effects of inhibitors were examined in the five diverse 4NPA concentrations for each inhibitor. The CA activities were measured for different concentrations of inhibitors in spectrophotometer cuvette $(1.0 \mathrm{~mL})$. Control activity was assumed to be $100 \%$ in the absence of inhibitor. Reduced $50 \%$ activity of enzyme by used inhibitor concentration ( $\left.\mathrm{IC}_{50}\right)$ was calculated from the graphs using conventional polynominal regression software (Microsoft Office 2010, Excel).

\section{Results}

In present study, CA enzyme was purified from the Shabut Fish (Barbus grypus) gill tissue for the first time. The purification of the gill CA was carried out in one stage by chromatography column on L-tyrosine sulfonamide coupled to Sepharose 4B. The Shabut Fish (Barbus grypus) gill CA was purified with a specific activity of $2.92 \mathrm{EU} / \mathrm{mg}$ protein (198.6-folds) with a yield of 58.8\% (Table 1).

To establishment of molecular weight of the enzyme, $\mathrm{R}_{\mathrm{f}}$ values were also calculated for the enzyme and standard proteins, and $\mathrm{R}_{\mathrm{f}}-\mathrm{Log} \mathrm{MW}$ graph was obtained according to Laemmli' method (Fig. 1). It was obtained a single protein band, evidence of purified enzyme having a molecular weight of the subunit was approximately $29.9 \mathrm{kDa}$, based on SDS-PAGE (Fig. 2). SDS-PAGE is one of the most greatly used laboratory methods to separate biological macromolecules including proteins and nucleic acids. In this 
separation method, macromolecules are differentiated according to their electrophoresis mobility, which is a function of the length, conformation, and charge of the molecule. Ordinarily, macromolecules as proteins may be run in their native state or in denatured forms. To separate molecules based on their lengths, samples are run in denaturing conditions (Atasever et al., 2013).

Some biochemical parameters of enzyme were investigated such as optimum $\mathrm{pH}$, optimum temperature and optimum ionic strength. The optimum $\mathrm{pH}$, optimum temperature and optimum ionic strength were determined to be 7.5 Tris- $\mathrm{SO}_{4}$ buffer, $40{ }^{\circ} \mathrm{C}$ and $50 \mathrm{mM}$ Tris- $\mathrm{SO}_{4}$ buffer for the CA enzyme, respectively. $\mathrm{K}_{\mathrm{M}}$ and $\mathrm{V}_{\max }$ values were calculated for NPA by Lineweaver-Burk graph. $\mathrm{K}_{\mathrm{M}}$ constants were calculated as $0.32 \mathrm{mM}, \mathrm{V}_{\max }$ values as $0.0025 \mathrm{~mol} \times \mathrm{min}^{-1}$ for NPA.

The inhibitory effects of some pesticides (Spinosad and Dimethoate) and metal ions $\left(\mathrm{Al}^{3+}, \mathrm{Cu}^{2+}, \mathrm{Ba}^{2+}, \mathrm{Fe}^{2+}, \mathrm{Mn}^{2+}, \mathrm{Se}^{2+}\right)$ on $\mathrm{CA}$ purified from the Shabut Fish (Barbus grypus) gill tissue were determined. For the compounds showing inhibitory effects, the $\mathrm{IC}_{50}$ value was determined by activity\% vs inhibitor concentration graphs for each compound. Table 2 shows the in vitro effect of metal ions $\left(\mathrm{Al}^{3+}, \mathrm{Cu}^{2+}, \mathrm{Ba}^{2+}, \mathrm{Fe}^{2+}, \mathrm{Mn}^{2+}\right.$ and $\mathrm{Se}^{2+}$ ) on CA purified from the Shabut Fish (Barbus grypus) gill tissue. IC 50 values of $\mathrm{Al}^{3+}, \mathrm{Cu}^{2+}, \mathrm{Ba}^{2+}, \mathrm{Fe}^{2+}$ and $\mathrm{Se}^{2+}$ ions were determined to be $0.355,3.46,0.77,0.303$ and $1.57 \mathrm{mM}$, respectively.

Inhibition data for some pesticides (Spinosad and Dimethoate) on this enzyme are exhibited in Table 3. Very low $\mathrm{IC}_{50}$ values were obtained such as 0.41 and $0.52 \mathrm{mM}$ in the presence of the Spinosad and Dimethoate as inhibitors (Fig. 3a, b).

Table 1. Summary of purification procedure of CA enzyme from Shabut Fish (Barbus grypus) gill tissue

\begin{tabular}{c|c|c|c|c|c|c|c|c}
\hline $\begin{array}{c}\text { Purification } \\
\text { Steps }\end{array}$ & $\begin{array}{c}\text { Activity } \\
(\mathbf{E U} / \mathbf{m l})\end{array}$ & $\begin{array}{c}\text { Total } \\
\text { volume } \\
(\mathbf{m l})\end{array}$ & $\begin{array}{c}\text { Protein } \\
(\mathbf{m g} / \mathbf{m l})\end{array}$ & $\begin{array}{c}\text { Total } \\
\text { protein } \\
(\mathbf{m g})\end{array}$ & $\begin{array}{c}\text { Total } \\
\text { activity }\end{array}$ & $\begin{array}{c}\text { Specific } \\
\text { activity } \\
(\mathbf{E U / m g})\end{array}$ & $\begin{array}{c}\text { Yield } \\
\mathbf{\%}\end{array}$ & $\begin{array}{c}\text { Purification } \\
\text { fold }\end{array}$ \\
\hline Homogenate & 45.33 & 30 & 2050 & 92250 & 1360 & 0.0147 & 100.0 & 1.0 \\
\hline $\begin{array}{c}\text { Sepharose-4B-L } \\
\text { tyrosine- } \\
\text { sulfanilamide } \\
\text { affinity } \\
\text { chromatography }\end{array}$ & 80 & 10 & 27.44 & 274.4 & 800 & 2.92 & 58.8 & 198.6 \\
\hline
\end{tabular}

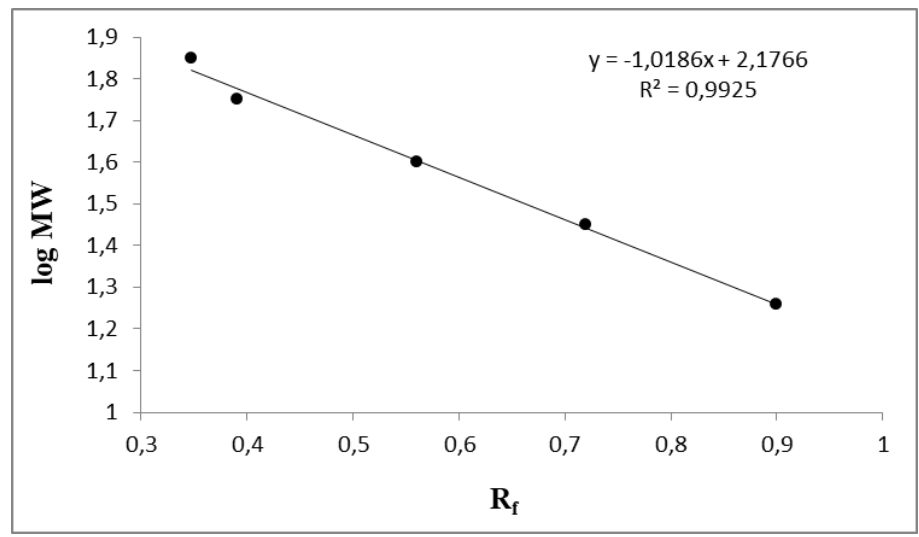

Figure 1. Standard $R_{f}-L o g M W$ graph molecular weight of CA from Shabut Fish (Barbus grypus) gill tissue using the SDS-PAGE results 


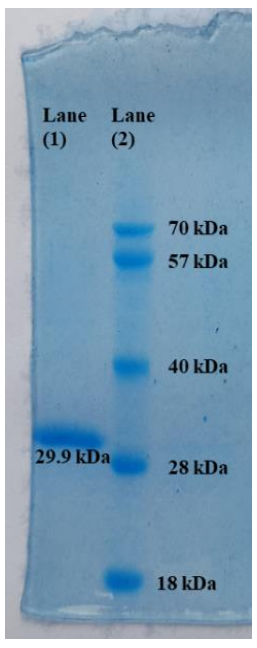

Figure 2. SDS-PAGE analysis of purified Shabut Fish (Barbus grypus) gill tissue CA enzyme. Lane (1) CA enzyme purified from the gill tissue of Shabut Fish (Barbus grypus), (29.9 kDa).

Lane (2) standard proteins $(70 \mathrm{kDa}),(57 \mathrm{kDa}),(40 \mathrm{kDa}),(28 \mathrm{kDa}),(18 \mathrm{kDa})$

Table 2. IC 50 values for metal ions on CA enzyme from Shabut Fish (Barbus grypus) gill tissue

\begin{tabular}{c|c|c|c}
\hline Inhibitors & IC $_{50}$ & Inhibitors & IC $_{\mathbf{5 0}}$ \\
\hline $\mathrm{Al}^{3+}$ & $0.355 \mathrm{mM}$ & $\mathrm{Se}^{2+}$ & $1.57 \mathrm{mM}$ \\
$\mathrm{Fe}^{2+}$ & $0.303 \mathrm{mM}$ & $\mathrm{Ba}^{2+}$ & $0.77 \mathrm{mM}$ \\
$\mathrm{Cu}^{2+}$ & $3.46 \mathrm{mM}$ & $\mathrm{Mn}^{2+}$ & No inhibition $(1-15 \mathrm{mM})$ \\
\hline
\end{tabular}

Table 3. IC 50 values for some pesticides on CA enzyme from Shabut Fish (Barbus grypus) gill tissue

\begin{tabular}{c|c|c|c}
\hline Inhibitors & IC $_{\mathbf{5 0}}$ & Inhibitors & IC50 \\
\hline Spinosad & $0.41 \mathrm{mM}$ & Dimethoate & $0.52 \mathrm{mM}$ \\
\hline
\end{tabular}

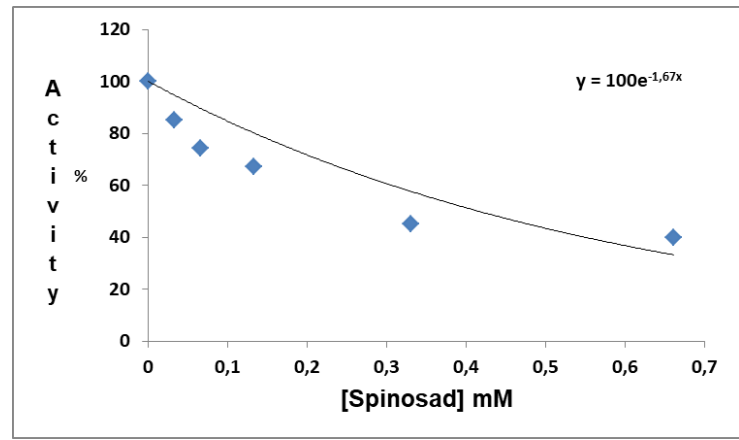

$\mathbf{a}$

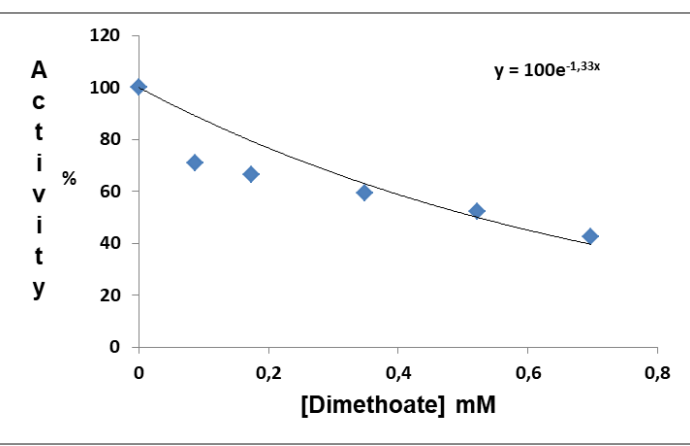

b

Figure 3. $I C_{50}$ graph of $\boldsymbol{a}$ Spinosad and $\boldsymbol{b}$ Dimethoate

These findings may be helpful for comparing CAs from different vertebrate species, their susceptibility to inhibition of various compound classes and also for understanding 
the toxic effect of some pesticides and metal ions in endangered fish species. Some physiological aspects of CA-mediated processes in this type of less investigated vertebrate are in fact poorly understood, since most of the CA pharmacological/environmental researches have been done with the human and rodent enzymes. This research made from fish gill is important in this aspect.

\section{Discussion and conclusion}

Metals and pesticides generally have a negative effect on metabolism. Pesticides commonly used in agricultural fields and metals with industrial waste are particularly important determinants of the health of land and aquatic organisms. In recent years, issues such as the rapid increase in the use of pesticides in agriculture and the disposal of industrial wastes to the environment are need attention. When the distribution of heavy metals in the ecological system is examined, it is observed that the human hand is more effective in spreading to the environment than natural cycles. Kacar et al. studied to determine the concentrations of heavy metals $(\mathrm{Cr}, \mathrm{Mn}, \mathrm{Fe}, \mathrm{Co}, \mathrm{Ni}, \mathrm{Cu}, \mathrm{Zn}, \mathrm{Cd}$ and $\mathrm{Pb}$ ) in liver, gill and muscle of Barbus grypus in Batman Dam, Turkey. Their results indicated that heavy metal concentrations were higher in the liver and gill, while it was lower in the muscle (Kacar et al., 2017a). In another study, Kacar et al. studied the heavy metal concentrations in the tissues of fish taken seasonally from the Batman Dam. Their results indicated that in the winter; $\mathrm{Cr}, \mathrm{Fe}, \mathrm{Ni}, \mathrm{Co}, \mathrm{Zn}$ and $\mathrm{Pb}$ accumulations in the gills were more than in all seasons (Kacar et al., 2017b).

$\mathrm{CO}_{2}$, produced in fish tissues, is hydrated quickly by the CA enzyme, converted into bicarbonate, and transported in the blood. Approximately, 98\% of the transported and stored $\mathrm{CO}_{2}$ is in the bicarbonate form (Demirdag et al., 2013). CA is a crucial enzyme in several other important physiological processes. For instance, the gills of aquatic organisms function in respiratory gas exchange, salt transport, and acid-base balance and CA can function in all three processes. The multiple functions of CA are a result of multiple isoforms that are localized to specific subcellular compartments/fractions within the gill (Cudennec et al., 2006; Sender et al., 1999). It has been understood that nearly all chemical reactions in the metabolism of the living organisms are catalyzed by enzymes, and the enzyme activities are influenced (decreased or increased) by many chemical substances including pesticides, fungicides, drugs and metal ions even at low concentrations (Soydan et al., 2017; Ozaslan et al., 2017). There are numerous studies about inhibition of CA enzyme activity with different pesticide and metals reported in the literature. For instance, Demirdag et al. investigated the inhibitory effects of some metals on the enzymatic activity of sheep liver CA. They found in vitro inhibition of the metals in the order of $\mathrm{Cu}^{2+}>\mathrm{Zn}^{2+}>\mathrm{Cd}^{2+}>\mathrm{Co}^{2+}>\mathrm{Ni}^{2+}$ (Demirdag et al., 2012a). In another study, Ceyhun et al. studied the inhibitory effects of some metals on the enzymatic activity of the teleost fish Dicentrarchus labrax liver CA. Their results indicated that metal ions $\left(\mathrm{Al}^{3+}, \mathrm{Cu}^{2+}, \mathrm{Pb}^{2+}, \mathrm{Co}^{3+}, \mathrm{Ag}^{1+}, \mathrm{Zn}^{2+}\right.$ and $\mathrm{Hg}^{2+}$ ) inhibited the enzyme activity at low concentrations $(0.0692,0.0715,0.1128,0.3165,0.3790,0.39$ and $0.4484 \mathrm{mM}$ ), respectively (Ceyhun et al., 2011). Furthermore, Demirdag et al. investigated inhibitor effects of pesticides such as cyhalothrin, cypermethrin, dichlorvos, methamidophos, chlorpyrifos and methylparathion on purified enzyme from the European Seabass liver (Demirdag et al., 2012b). They showed that pesticides inhibit the enzyme even at very small concentrations. Soydan et al. studied the inhibitory effects of some pesticides on the enzymatic activity of Apis mellifera CA. 
Their results indicated that $\mathrm{IC}_{50}$ values for the tebuconazole, propoxur, carbaryl, carbofuran, simazine and atrazine pesticides were 0.0030, 0.0321, 0.0031, 0.0087, 0.0273 and $0.0165 \mathrm{mM}$, respectively (Soydan et al., 2017). In another study, K1linc et al. studied the inhibitory effects of chlorpyrifos, cypermethrin, dichlorvos, glyphosate isopropylamine and lambda cyhalomethrin pesticides on the enzymatic activity of the sheep stomach CA-II. Their results indicated that glyphosate isopropylamine and dichlorvos were found to have the highest inhibitory effects on the purified enzyme (K1linc et al., 2015). From the studies mentioned above, it can be distinctly understood that many pesticides and metals have inhibitory effects on CA enzyme activity. Hence, in this study; the inhibitory effects of some widely used pesticides and metals on the activity of purified Shabut Fish (Barbus grypus) gill CA enzyme are investigated (Tables 2 and 3). As gill carbonic anhydrases contact primary with habitat of fish, investigation of these functions' performance is necessary how affected by environmental factors. In this study, the carbonic anhydrase enzyme was purified for the first time from Shabut Fish (Barbus grypus) gill tissue, in a single step, by using affinity chromatography. Furthermore, this enzyme has been inhibited by the some pesticides inhibitors (Spinosad and Dimethoate), with the $\mathrm{IC}_{50}$ values of $0.41 \mathrm{mM}$ and $0.52 \mathrm{mM}$, respectively.

Hisar et al. (2006) reported that the CA was purified 104.8-folds with a specific activity of 55.6 EUx (mg protein) ${ }^{-1}$ from the rainbow trout gills by using Sepharose 4BL-tyrosine-sulfanilamide affinity column. (Demirdag et al., 2015) purified a fish enzyme from Agrı Balık Lake trout gill (Salmo trutta labrax) and achieved a purification of 303.9-folds with a specific activity of 4130.4 EUx (mg protein) $)^{-1}$ and recovery of $79.3 \%$ using the identical technique. It is indicated that the carbonic anhydrases derived from various organisms have molecular mass of from 18.9 to $29.3 \mathrm{kDa}$ (Smith and Ferry, 2000). The subunit molecular weight of the Shabut Fish (Barbus grypus) gill CA enzyme was found to be about $29.9 \mathrm{kDa}$ by SDS-PAGE. The values obtained are in harmony with the literature as seen. Dincer et al. (2016) reported that the molecular weight of the gill CA from Russian Sturgeon Fish (Acipenser gueldenstaedtii) is about $29 \mathrm{kDa}$ while Hisar et al. (2006) reported that it to be $27 \mathrm{kDa}$ from the rainbow trout gills and $29 \mathrm{kDa}$ from Russian Sturgeon Fish erythrocyte (Kolayli et al., 2011).

Data of Table 2 show that the gill CA was inhibited by metal ions, with $\mathrm{IC}_{50}$ values in the range of $0.303-3.46 \mathrm{mM}$. The most inhibitory ion was Fe (II) and the least inhibitory was $\mathrm{Cu}$ (II). Heavy metals possess different toxicological impacts on living organisms, especially in fish. It is that enter the food chain are not discharged from fish and are so accumulated in their bodies. Then, they can be ingested by humans via the consumption of fish. Thus, heavy metal ions probably do constitute a great danger for this fish, or at least they do inhibit significantly the CA found in the gill. Pesticides have been found to be a more potent inhibitor of gill CA when it is compared to heavy metals. It was observed that some pesticides such as (Spinosad and Dimethoate) inhibited the enzyme at very small concentrations such as 0.41 and $0.52 \mathrm{mM}$. Most of the enzyme studies in the literature are on humans and animals. Researches on the effects of environmental pollutants such as pesticides and metals on fish are limited. As the number of such studies demonstrating the metabolic effects of environmental pollutants on fish increases, we can become a more conscious society. It would be beneficial for researchers to give direction to their research by taking this into consideration. 
Consequently, Shabut Fish (Barbus grypus) gill CA enzyme was purified in a one step affinity chromatography procedure for the first time, and analyzed characteristic features. In addition, inhibitory effects of some pesticides and metals on enzyme activity were reported. In the light of these results, the Shabut Fish (Barbus grypus) gill CA enzyme is inhibited by some environmental pollutants such as pesticides (Spinosad and Dimethoate) and metal ions $\left(\mathrm{Al}^{3+}, \mathrm{Cu}^{2+}, \mathrm{Ba}^{2+}, \mathrm{Fe}^{2+}\right.$ and $\left.\mathrm{Se}^{2+}\right)$. Owing to their toxicity, pesticides and metal ions affect not only the target organisms but also animals and humans which are being exposed to these compounds. Therefore, some measures have to be taken to prevent excessive diffusion to the environment when using these compounds. As a precaution, farmers should be informed about the use of pesticides and trained on this subject at short intervals. Besides, harmful effects on health of these chemical substances must be considered carefully and the usage of them must be kept under control. The industries near the water supplies must be more conscious about the factory waste and metal residues. The fish in fresh water and sea have been consumed as an important food source until now and will be consumed in the future. Thus, due to the mixing of the pesticides through the rain and irrigation waters into the Siirt/Botan Stream, aquatic organisms in this area are at great risk of chemical toxicity.

\section{REFERENCES}

[1] Anwar, W. A. (1997): Biomarkers of human exposure to pesticides. - Environment Health Perspectives 105: 801-806.

[2] Atasever, A., Ozdemir, H., Gulcin, I., Kufrevioglu, O. I. (2013): One-step purification of lactoperoxidase from bovine milk by affinity chromatography. - Food Chem. 136(2): 864-870.

[3] Bradford, M. M. (1976): A rapid and sensitive method for the quantitation of microgram quantities of protein utilizing the principle of protein-dye binding. - Anal Biochem 72: 248-254.

[4] Cerqueira, C. C., Fernandes, M. N. (2002): Gill tissue recovery after copper exposure and blood parameter responses in the tropical fish Prochilodus scrofa. - Ecotoxicol. Environ. Saf. 52: 83-91.

[5] Ceyhun, S. B., Senturk, M., Erdogan, O., Kufrevioglu, O. I. (2010): In vitro and in vivo effects of some pesticides on carbonic anhydrase enzyme from rainbow trout (oncorhynchus mykiss) gills. - Pestic Biochem Physiol 97: 177-181.

[6] Ceyhun, S. B., Senturk, M., Yerlikaya, E., Erdogan, O., Kufrevioglu, O. I., Ekinci, D. (2011): Purification and characterization of carbonic anhydrase from the teleost fish Dicentrarchus labrax (European seabass) liver and toxicological effects of metals on enzyme activity. - Environ Toxicol Pharm. 32: 69-74.

[7] Cudennec, B., Rousseau, M., Lopez, E., Fouchereau-Peron, M. (2006): CGRP stimulates gill carbonic anhydrase activity in molluscs via a common CT/CGRP receptor. - Peptides 27: 2678-2682.

[8] Demir, Y., Oruc, E., Topal, A. (2016): Carbonic anhydrase activity responses and histopathological changes in gill and liver tissues after acute exposure to chromium in brown trout juvenile. - Hacettepe J. Biol. Chem. 44(4): 515-523.

[9] Demirdag, R., Comakli, V., Kuzu, M., Yerlikaya, E., Senturk, M. (2015): Purification and characterization of carbonic anhydrase from Agrı Balık Lake trout gill (Salmo trutta labrax) and effects of sulfonamides on enzyme activity. - J Biochem Molecular Toxicology 29(3): 123-128. 
[10] Demirdag, R., Comakli, V., Senturk, M., Ekinci, D., Kufrevioglu, O. I., Supuran, C. T. (2013): Purification and characterization of carbonic anhydrase from sheep kidney and effects of sulfonamides on enzyme activity. - Bioorg Med Chem 21: 1522-1525.

[11] Demirdag, R., Yerlikaya, E., Aksakal, E., Kufrevioglu, O. I., Ekinci, D. (2012b): Influence of pesticides on the $\mathrm{pH}$ regulatory enzyme, carbonic anhydrase, from European Seabass liver and bovine erythrocytes. - Environ Toxicol Pharm. 34: 218-222.

[12] Demirdag, R., Yerlikaya, E., Kufrevioglu, O. I. (2012a): Purification of carbonic anhydrase-II from sheep liver and inhibitory effects of some heavy metals on enzyme activity. - J Enzyme Inhib Med Chem. 27(6): 795-799.

[13] Dincer, B., Ekinci, A. P., Akyuz, G., Kurtoglu, I. Z. (2016): Characterization and inhibition studies of carbonic anhydrase from gill of Russian Sturgeon Fish (Acipenser gueldenstaedtii). - J Enzyme Inhib Med Chem. 31(6): 1662-1665.

[14] Ekinci, D., Beydemir, S. (2010): Purification of PON1 from human serum and assessment of enzyme kinetics against metal toxicity. - Biol Trace Elem Res. 135: 112120.

[15] Ekinci, D., Beydemir, S., Kufrevioglu, O. I. (2008): In vitro inhibitory effects of some heavy metals on human erythrocyte carbonic anhydrases. - J Enzyme Inhib Med Chem. 22(6): 745-750.

[16] Hisar Aras, S., Hisar, O., Yanık, T., Aras, S. M. (2004): Inhibitory effects of ammonia and urea on gill carbonic anhydrase enzyme activity of rainbow trout (Oncorhynchus mykiss). - Environ Toxicol Pharm 17: 125-128.

[17] Hisar, O., Beydemir, S., Bulbul, M., Yanık, T. (2006): Kinetic properties of carbonic anhydrase purified from gills of rainbow trout (Oncorhynchus mykiss). - J Appl Anim Res 30: 185-188.

[18] Kacar, E., Karadede Akın, H., Cicek, T., Unlu, E. (2017b): Seasonal variations of heavy metals in water, sediment and tissues of two freshwater fish species (Cyprinion macrostomum and Capoeta trutta) from the Batman Dam (Tigris Basin), Turkey. Fresenius Environmental Bullet 26(6): 4187-4193.

[19] Kacar, E., Karadede Akın, H., Ugurlu, P. (2017a): Determination of heavy metals in tissues of Barbus grypus (Heckel, 1843) from Batman Dam, Turkey. - Turkish Journal of Fisheries and Aquatic Sciences 17: 787-792.

[20] Kilınc, N., Isgor, M. M., Sengül, B., Beydemir, S. (2015): Influence of pesticide exposure on carbonic anhydrase II from sheep stomach. - Toxicology and Industrial Health 31(9): 823-830.

[21] Koca, Y. B., Koca, S., Yildiz, S., Gurcu, B., Osanc, E., Tuncbas, O., et al. (2005): Investigation of histopathological and cytogenetic effects on Lepomis gibbosus (Pisces: Perciformes) in the Cine stream (Aydin/Turkey) with determination of water pollution. Environ. Toxicol. 20: 560-571.

[22] Kolayli, S., Karahalil, F., Sahin, H., et al. (2011): Characterization and inhibition studies of an a-carbonicanhydrase from the endangered sturgeon species Acipenser gueldenstaedti. - J Enzyme Inhib Med Chem.26: 895-900.

[23] Laemmli, U. K. (1970): Cleavage of structural proteins during the assembly of the head of bacteriophage T4. - Nature 227: 680-5.

[24] Lineweaver, H., Burk, D. (1934): The determination of enzyme dissocation constants, J. Am. Chem. Soc., 56(3): 658-666.

[25] Lopez Mananes, A. A., Magnoni, L. J., Goldemberg, A. L. (2000): Brancial carbonic anhydrase (CA) of gills of Chasmagnathus granulata (Crustacea decapoda). - Comp Biochem Physiol 127B: 85-95.

[26] Olgunoglu, A. I., Olgunoglu, M. P., Artar, E. (2011): Seasonal changes in biochemical composition and meat yield of Shabut (Barbus grypus, Heckel 1843). - Iranian Journal of Fisheries Sciences Short Communication 10(1): 181-187. 
[27] Ozaslan, M. S., Demir, Y., Kufrevioglu, O. I., Ciftci, M. (2017): Some metals inhibit the Glutathione S-transferase from Van Lake fish gills. - J Biochem Mol Toxicol. 31: e21967. https://doi.org/10.1002/jbt.21967.

[28] Randall, D. J., Daxbaeck, C. (1984): Oxygen and Carbon Dioxide Transfer across Fish Gills. - In: Hoar, W. S., Randall, D. J. (eds.) Fish Histology. Vol. 10A. Academic Press, New York.

[29] Sender, S., Bottcher, K., Cetin, Y., Gros, G. (1999): Carbonic anhydrase in the gills of seawaterand freshwater-acclimated flounders Platichthys flesus: purification, characterization, and immunohistochemical localization. - J Histochem Cytochem 47: 43-50.

[30] Senturk, M., Gulcin, I., Beydemir, S., Kufrevioglu, O. I., Supuran, C. T. (2011): In Vitro inhibition of human carbonic anhydrase I and II isozymes with natural phenolic compounds. - Chem. Biol. Drug Des. 77(6): 494-499.

[31] Singh, N., Gupta, K. V., Kumar, A., Sharma, B. (2017): Synergistic effects of heavy metals and pesticides in living systems. - Frontiers in Chemistry 5: 70.

[32] Smith, K. S., Ferry, J. G. (2000): Prokaryotic carbonic anhydrases, reviews. - FEMS Microbiol 24: 335-366.

[33] Soydan, E., Guler, A., Biyık, S., Senturk, M., Supuran, C. T., Ekinci, D. (2017): Carbonic anhydrase from Apis mellifera: purification and inhibition by pesticides. - J Enzyme Inhib Med Chem. 32(1): 47-50.

[34] Soyut, H., Beydemir, S. (2008): Purification and some kinetic properties of carbonic anhydrase from rainbow trout (Oncorhynchus mykiss) liver and metal inhibition. Protein Pept. Lett. 15(5): 528-535.

[35] Supuran, C. T. (2018): Carbonic Anhydrases and Metabolism. - Metabolites 8(2): 25.

[36] Tiemann, U. (2008): In vivo and in vitro effects of the organochlorine pesticides DDT, TCPM, methoxychlor, and lindane on the female reproductive tract of mammals: a review. - Reprod Toxicol. 25(3): 316-326.

[37] Topal, A., Atamanalp, M., Oruc, E., Demir, Y., Beydemir, S., Isik, A. (2014): In vivo changes in carbonic anhydrase activity and histopathology of gill and liver tissues after acute exposure to chlorpyrifos in rainbow trout. - Arh. Hig. Rada Toksikol. 65: 377-385.

[38] Verpoorte, J. A., Mehta, S., Edsall, J. T. (1967): Esterase activities of human carbonic anhydrases B and C. - J Biol Chem 242: 4221-9. 